\title{
Production, respiration, and photophysiology of the mangrove jellyfish Cassiopea xamachana symbiotic with zooxanthellae: effect of jellyfish size and season
}

\author{
E. Alan Verde ${ }^{1, *}$, L. R. McCloskey ${ }^{2}$ \\ ${ }^{1}$ Oregon State University, Department of Zoology, 3029 Cordley Hall, Corvallis, Oregon 97331, USA \\ ${ }^{2}$ La Sierra University, Department of Biology, 4700 Pierce Street, Riverside, California 92515, USA
}

\begin{abstract}
The association between the symbiont Symbiodinium microadriaticum (zooxanthellae) and its host jellyfish, Cassiopea xamachana, was investigated as a function of jellyfish size and season. Symbiont cell diameter and volume were higher during January than September. Although zooxanthella-specific chlorophyll was independent of jellyfish size, both chlorophyll a and $c$ were higher during January. Regardless of season, algal density and jellyfish size were inversely related. The diel mitotic index (MI) of zooxanthellae was phased, with a peak of $0.25 \%$ occurring between 09:00 and 12:00 h. September photosynthetic rates were always higher than January rates and reflected the seasonal light and temperature regimes at the latitude of the Florida Keys (USA). Photosynthesis, when normalized to either zooxanthella density or protein, displayed an inverse relationship with jellyfish

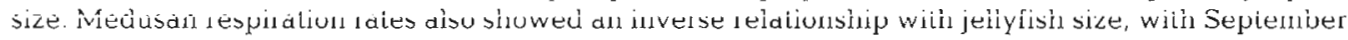
metabolism being higher than that of January. The carbon budgets calculated for these medusae indicate that the carbon photosynthetically fixed by the zooxanthellae, and subsequently translocated to the host, is capable of satisfying about $169 \%$ of the host's metabolic demand (CZAR) and is independent of both jellyfish size and season. These seasonally influenced physiological effects underscore the necessity for seasonal examinations of algal-cnidarian symbioses in order to understand the photophysiology of the association on an annual basis.
\end{abstract}

KEY WORDS: Cassiopea xamachana - Zooxanthellae - Jellyfish Photosynthesis - Respiration · Photophysiology $\cdot$ Carbon budgets $\cdot$ CZAR

\section{INTRODUCTION}

The relationship between marine unialgal symbionts (zooxanthellae) and cnidarian hosts has been more widely studied for benthic cnidarians (reviews by Muscatine 1990, Battey 1992, Davies 1992, Trench 1993) than for motile ones. Early studies on the scyphozoan Cassiopea sp. showed that endosymbiotic zooxanthellae (Symbiodinium) are capable of $\mathrm{CO}_{2}$ uptake and fixation (Balderston \& Claus 1969, Drew 1972) and subsequent carbon translocation to host tissues (Balderston \& Claus 1969). Cates (1975) suggested that these photosynthesis-respiration interactions enhance the ecological efficiency of Cassiopea sp. due to the presence

•E-mail: verdea@bcc.orst.edu of zooxanthellae. Differences in the excretion rates of ammonia between aposymbiotic and symbiotic Cassiopea sp. suggest that the zooxanthellae remove hostproduced ammonia and aid in the recycling of nitrogen (Cates \& McLaughlin 1976). Hofmann \& Kremer (1981) and Hofmann et al. (1996) investigated the importance of zooxanthellae to strobilation in Cassiopea andromeda and reported that the presence of algae was indispensable although algal photosynthesis or photosynthate release was not essential for this process. Apparently, the symbiotic zooxanthellae produce and supply a 'factor' which promotes the elevated metabolism required for proceeding through developmental stages (Rahat \& Hofmann 1987).

The photosynthetic carbon budget of the epipelagic coronate medusa Linuche unguiculata has been inves- 
tigated by Kremer et al. (1990); zooxanthellae from these medusae are capable of contributing carbon products towards host respiratory requirements (CZAR) of approximately $160 \%$. A similar study on the swimming rhizostomid medusa Mastigias sp. was conducted by McCloskey et al. (1994); CZAR estimates averaged 97 and $176 \%$ for lake and lagoon ecotypes, respectively. In contrast to both $L$. unguiculata and Mastigias sp., Cassiopea xamachana is more sedentary, spending most of its time with the bell's exumbrella in direct contact with the substrate and its tentacles elevated towards the surface (Blanquet \& Phelan 1987). Therefore, we wanted to investigate whether or not these semi-sedentary medusae rely as much on symbiont-derived organic products for metabolism as do L. unguiculata and Mastigias sp.

To our knowledge, no study estimating the photosynthetic capabilities and resultant carbon budgets of scyphozoans has investigated these parameters as a function of seasonal environmental changes. Most photosynthesis-respiration estimates are based on a single-case time period, as is the case for Linuche unguiculata (Kremer et al. 1990), Mastigias sp. (McCloskey et al. 1994), and Cassiopea xamachana (Vodenichar 1995). The few seasonal-based studies on scyphozoans have only dealt with jellyfish population dynamics or distributions (Brewer \& Feingold 1991, Olesen et al. 1994) or growth (Olesen et al. 1994). With respect to medusan size, 2 studies on Mastigias sp. are the only investigations that have documented the influence of jellyfish size on photosynthesis, respiration, and carbon budgets (McCloskey et al. 1994) and algal symbiont population density and regulation. (Muscatine et al. 1986). Consequently, we also wanted to determine if medusan size or seasonal environmental change affects the carbon budgets of C. xamachana symbiotic with Symbiodinium microadriaticum (Freudenthal 1962, Trench \& Blank 1987).

\section{MATERIALS AND METHODS}

Collection and processing of jellyfish. Different-sized specimens of Cassiopea xamachana were collected daily from a shallow, mangrove-lined lagoon at Little Conch Key (mile marker 62.3) in the Florida Keys (USA). Al]. production and respiration experiments were conducted during September 1992 and January 1993. After each experiment, bell diameter, wet weight (ww), and displacement volume of each jellyfish were measured. The jellyfish were individually homogenized in filtered seawater (Whatman no. 5 filter), the homogenate volume determined, and sub-samples taken for various assays. Each jellyfish was assigned to 1 of 3 size classes based on bell diameters: small, medium, or large.
Algal parameters. Chlorophylls: After homogenization of each jellyfish, the algae were obtained by 3 centrifugations, each at 3 to 4 min at top speed in a clinical centrifuge, with the algal pellet resuspended each time in filtered seawater. Three replicate aliquots $(3.0 \mathrm{ml}$ each) of resuspended algae were processed as described by Verde \& McCloskey (1996). Between 15 and 20 hemacytometer grids were counted to obtain algal density (cells $\mathrm{ml}^{-1}$ ) of the suspension which was used for chlorophyll assays. The chlorophyll content was calculated using the equations of Jeffrey \& Humphrey (1975) as modified by Parsons et al. (1984).

Density, size, and biomass: Algal numbers from 20 replicate samples from each homogenate were counted with a hemacytometer and converted to total standing stock of algae per jellyfish. Concurrently, the diameters of 20 randomly chosen zooxanthellae were measured from each jellyfish homogenate. For biomass studies, freshly collected jellyfish ( $\mathrm{n}=4$, January and September) were individually homogenized in filtered seawater. Aliquots of the algal suspension were centrifuged for 3 to $4 \mathrm{~min}$ in a clinical centrifuge and the jellyfish tissue layer above the algal pellet was discarded. Jellyfish contamination of the algal suspension was periodically checked by hemacytometer counts; after the algal:nematocyst ratio exceeded $95 \%, 20$ hemacytometer grids were counted to obtain algal density (cells $\mathrm{m}^{-1}$ ).

Samples for C:N analysis were prepared for isolated algae as follows. Either $2.0 \mathrm{ml}$ or $3.0 \mathrm{ml}$ of the jellyfishfree algal cell suspension was filtered, under gentle vacuum, through a precombusted $\left(450^{\circ} \mathrm{C}\right.$ for $\left.12 \mathrm{~h}\right)$ GF/C filter (25 mm Whatman). Each filter was subsequently rinsed with $0.5 \mathrm{ml}$ of distilled water, to remove salts, and frozen. Four seawater-filter blanks were included in all sample sets as controls. Prior to $\mathrm{C}: \mathrm{N}$ analysis, the filters were dried $\left(45^{\circ} \mathrm{C}\right.$ for $\left.12 \mathrm{~h}\right)$ and the carbon and nitrogen masses quantified using a Control Equipment Corporation Elemental Analyzer (Model 240X). After accounting for seawater blanks, the algal carbon and nitrogen masses (pg cell ${ }^{-1}$ ) were calculated. The nitrogen mass was multiplied by 6.25 to obtain protein per algal cell (Muscatine et al. 1986).

Mitotic index and growth: Tentacle snips chosen at random from freshly collected and individually marked medusae (January and September) were collected every hour for $24 \mathrm{~h}$ and frozen. Each sample was homogenized and the dividing algal cells counted in a hemacytometer. The mitotic index (MI) was calculated as described by Wilkerson et al. (1983). The phaseddivision formulae of Vaulot (1992) was used to calculate the algal-specific growth $(\mu)$

$$
\mu=\ln \left[\left(1+f_{\max }\right)\left(1+f_{\min }\right)^{-1}\right]
$$

where $f_{\max }$ and $f_{\text {min }}$ are the maximum and minimum daily fraction of dividing cells, respectively. 
Jellyfish and algal biomass. Frozen aliquots of the jellyfish homogenate were thawed and the protein content of the medusan fraction estimated by the BCA Protein Assay (Pierce Chemical) using bovine serum albumen (fraction $V$ ) as the standard. Total jellyfish biomass was determined as medusan and algal protein fractions combined. Individual medusan and algal biomasses, expressed as fractions of total protein, are referred to as $\beta$ and $1-\beta$, respectively (Muscatine et al. 1981).

Photosynthesis and respiration parameters. The diel oxygen fluxes of intact jellyfish were measured with a self-contained underwater respirometer (McCloskey et al. 1985) at a depth of $2.0 \pm 0.5 \mathrm{~m}$. Simultaneously, ambient light intensity was measured with a Li-Cor quantum sensor (Model LI-192S). From data obtained from each $24 \mathrm{~h}$ record of oxygen flux, the integrated total daily jellyfish respiration and gross photosynthetic rate were determined as outlined by McCloskey et al. (1994) and Verde \& McCloskey (1996). Morning photosynthesis and irradiance (P-I) response curves were generated from diel oxygen flux measurements. For P-I analysis, hourly net photosynthesis was normalized to algal density and the curves were iteratively fit via the hyperbolic tangent function (Jassby \& Platt 1976)

Carbon budgets. The carbon budget parameters of Cassiopea xamachana were modclled using the nomenclature and equations of McCloskey et al, (1994). The contribution of carbon from zooxanthellae to animal respiration (CZAR) was calculated as described by McCloskey et al. (1994) and Verde \& McCloskey (1996).

Statistical analysis. Prior to analysis, all data sets were tested for compliance with the assumptions of each statistical test. If assumptions were violated, the data were transformed and retested, or non-parametric tests were utilized. All percentage data (i.e. the MI data) were arcsine transformed before analysis (Sokal \& Rohlf 1995, Zar 1996). The software packages Statistica $\backslash W^{\circ}$ (Statsoft, Inc.) and SlideWrite Plus (Advanced Graphics Software) were used to conduct statistical and graphics analysis, respectively.

\section{RESULTS}

\section{Environmental parameters}

Average ( \pm SD) daylength during January (11.2 \pm $0.1 \mathrm{~h}, \mathrm{n}=14$ ) was significantly shorter ( $t$-test, $\mathrm{p}<0.001$ ) than during September $(12.8 \pm 0.1 \mathrm{~h}, \mathrm{n}=10)$. Average daily integrated irradiance during January (31.0 \pm $9.6 \mathrm{E} \mathrm{m}^{-2} \mathrm{~d}^{-1}$ ) was significantly lower ( $t$-test, $\mathrm{p}<0.001$ ) than during September $\left(46.0 \pm 9.2 \mathrm{E} \mathrm{m}^{-2} \mathrm{~d}^{-1}\right)$. Likewise, water temperature during January was significantly lower than during September. Average ( \pm SD) January water temperature $\left(24.2 \pm 1.4^{\circ} \mathrm{C}, \mathrm{n}=14\right)$ during the night (when respiration was measured) was significantly lower (t-test, p $<0.001$ ) than for September $\left(29.9 \pm 0.5^{\circ} \mathrm{C}, \mathrm{n}=10\right)$

\section{Algal parameters}

Cell size. Since no significant differences (ANOVA, $p>0.05$ ) in algal diameters as a function of jellyfish size during either January or September occurred, the cell diameters from the 3 jellyfish sizes were pooled together. The average ( $\pm \mathrm{SD}$ ) algal cell diameter for January was $9.08 \mu \mathrm{m}( \pm 0.87, \mathrm{n}=540)$ and was significantly higher ( $t$-test, $\mathrm{p}<0.001)$ than the average of 8.64 un $( \pm 0.81, n=820$ ) for algal cells during September. It follows that the average cell volume for algae in January of $400.6 \mu^{3}$ ( $\pm 106.8, n=540$ ) was significantly higher ( $t$-test, $\mathrm{p}<0.001$ ) than the average volume of $347.7 \mu^{3}( \pm 103.8, n=820)$ for algae in September.

Chlorophyll. Zooxanthella chlorophylls a and $c$ (chl a and chl c) were significantly higher during January than September (Table 1, Fig. 1A, B). However, there was no significant difference in symbiont chlorophyll per cell as a function of jellyfish size. The chl a:chl $c$ ratio was not significantly different regardless of season or jellyfish size (Table 1, Fig. 1C).

Density and biomass. Since no significant differences between algal densities occurred during January and September, the data were pooled together

Table 1. Symbiodinium microadriatucum. Mean ( $\mathrm{SD}$ ) chlorophyll content (chl; pg cell-1) and chl a:chl cratio of zooxanthellae isolated from the jellyfish Cassiopea xamachana during September $1992(\mathrm{n}=27$ ) and January 1993 ( $\mathrm{n}=40$ ). The Student's $t$-test was used to determine significance between January and September values. ns: not significant $(p>0.05), \cdots p<0.001$

\begin{tabular}{|c|c|c|c|c|}
\hline Chlorophyll & January & September & Significance & Jan:Sep ratio \\
\hline Chl a & $2.21 \pm 0.35$ & $1.45 \pm 0.27$ & $\cdots$ & 1.52 \\
\hline $\mathrm{Chl} c$ & $0.66 \pm 0.10$ & $0.42 \pm 0.08$ & $\cdots$ & 1.57 \\
\hline Chl $a+c$ & $2.87 \pm 0.43$ & $1.87 \pm 0.34$ & $\cdots$ & 1.53 \\
\hline Chl a:chl $c$ ratio & $3.37 \pm 0.29$ & $3.49 \pm 0.49$ & ns & 0.96 \\
\hline
\end{tabular}




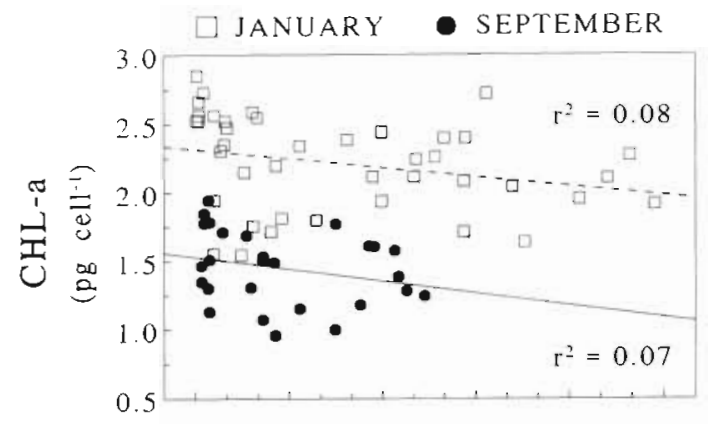

A



B

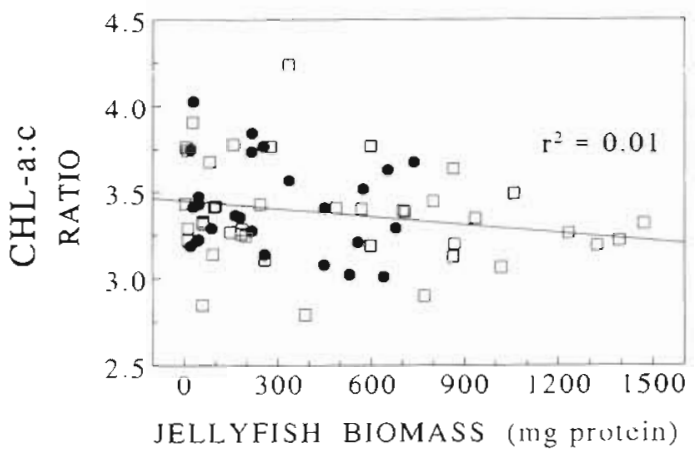

Fig. 1. Symbiodinium microadriaticum and Cassiopea xamachana. Chlorophyll content of zooxanthellae from C. xamachana as a function of jellyfish. size and season. Best-fit curve for the relationship between chlorophyll and host biomass is linear regression. (A) Chl a, January $r^{2}=0.08$, September $r^{2}=$ 0.07 ; (B) chl $c$, January $\mathrm{r}^{2}=0.03$, September $\mathrm{r}^{2}=0.01$; (C) chl a:chl c ratio, combined $\mathrm{r}^{2}=0.01$. The slopes from each figure are not significantly different $(p>0.05)$ from zero and only the $r^{2}$ value is listed. Sample sizes for January and September were 41 and 27 , respectively

(Fig. 2A). Jellyfish bell diameter and algal density were inversely related, with smaller jellyfish containing significantly higher algal cell densities than larger jellyfish (Fig. 2B). With regard to algal biomass, both the carbon content and C:N ratio of zooxanthellae were significantly higher during January than September (Table 2), but the nitrogen and resultant protein masses were not significantly different regardless of season. The pooled averages $( \pm S D)$ for January and September nitrogen and protein values were $15.23 \mathrm{pg}$ cell $^{-1}( \pm 1.63, \mathrm{n}=8)$ and $95.16 \mathrm{pg} \mathrm{cell}^{-1}( \pm 10.20, \mathrm{n}=8)$, respectively.
Mitotic index and growth. An average $( \pm \mathrm{SD})$ of $74.5 \%( \pm 8.3, n=20)$ of the algal symbionts resided solely within the tentacles, with the remaining $25.5 \%$ $( \pm 8.3, \mathrm{n}=20$ ) inhabiting the bell. The average symbiont MI from the tentacles of Cassiopea xamachana was $0.047 \%( \pm 0.068, \mathrm{n}=20)$ and from the bell was $0.084 \%( \pm 0.095, n=20)$, values which were not significantly different (paired $t$-test, $\mathrm{p}>0.05$ ). The $\mathrm{MI}$ values were significantly different (ANOVA, $\mathrm{p}<0.05$ ) throughout a diel period regardless of season and jellyfish size (Fig. 3). The near midday MI peak was significantly higher than the rest of the day (Tukey, p < 0.05 ) and we interpret this as phased mitosis. The maximum peaks of the MI, regardless of season or jellyfish size, were not significantly different (ANOVA, $p>$ $0.05)$ and the grand mean $( \pm \mathrm{SD})$ was $0.25 \%( \pm 0.20, \mathrm{n}=$ 72). Likewise, the MI minimums were not significantly different (ANOVA, $p>0.05$ ) and the grand mean was $0.02 \%( \pm 0.03, n=72)$. Consequently, the algal-specific


Fig. 2. Symbiodinium microadriaticum and Cassiopea xam achana. Density of zooxanthellae within C. xamachana as a function of jellyfish size and season. Best-fit curve for the relationship between algal density and host biomass $(A)$ is a power function: Densily $=4.82$ (Biomass) $^{-018}, r^{2}=0.64$. For the relationship between algal density and host bell diameter (B) horizontal lines connect algal densities that are not signif cantly different (Tukey, $p>0.05$ ); lines at different levels signify densities that are significantly different (Tukey, $\mathrm{p}<0.05$ ). Values above error bars are the mean (density) for each bell size class and values within bars represent sample size. Error bars show $\pm \mathrm{SD}$. Bell diameter $(\mathrm{cm}, \bar{x} \pm \mathrm{SD})$ of each size class, regardless of season, was: Small, $4.0 \pm 1.1$; Medium, $8.0 \pm 0.8$; Large, $13.0 \pm 2.2$ 
Table 2. Symbiodinium microadriaticum. Mean ( \pm SD) carbon, nitrogen, and protein contents $\left(\mathrm{pg}\right.$ cell $\left.{ }^{-1}\right)$ and $\mathrm{C}: \mathrm{N}$ ratio of zooxanthellae isolated from the jellyfish Cassiopea xamachana during September $1992(\mathrm{n}=4)$ and January 1993 ( $\mathrm{n}=4$ ). The Mann-Whitney $U$-test was used to determine significance between January and September values. ns: not significant ( $p>0.05)$, $\cdot p<0.05$

\begin{tabular}{|c|c|c|c|c|}
\hline Algal parameter & January & September & Significance & Jan:Sep ratio \\
\hline Carbon & $114.88 \pm 9.40$ & $85.29 \pm 9.27$ & - & 1.34 \\
\hline Nitrogen & $15.89 \pm 1.83$ & $14.56 \pm 1.30$ & ns & 1.09 \\
\hline Protein & $99.34 \pm 11.43$ & $90.98 \pm 8.11$ & ns & 1.09 \\
\hline C: $N$ ratio & $7.30 \pm 1.05$ & $5.87 \pm 0.49$ & - & 1.24 \\
\hline
\end{tabular}

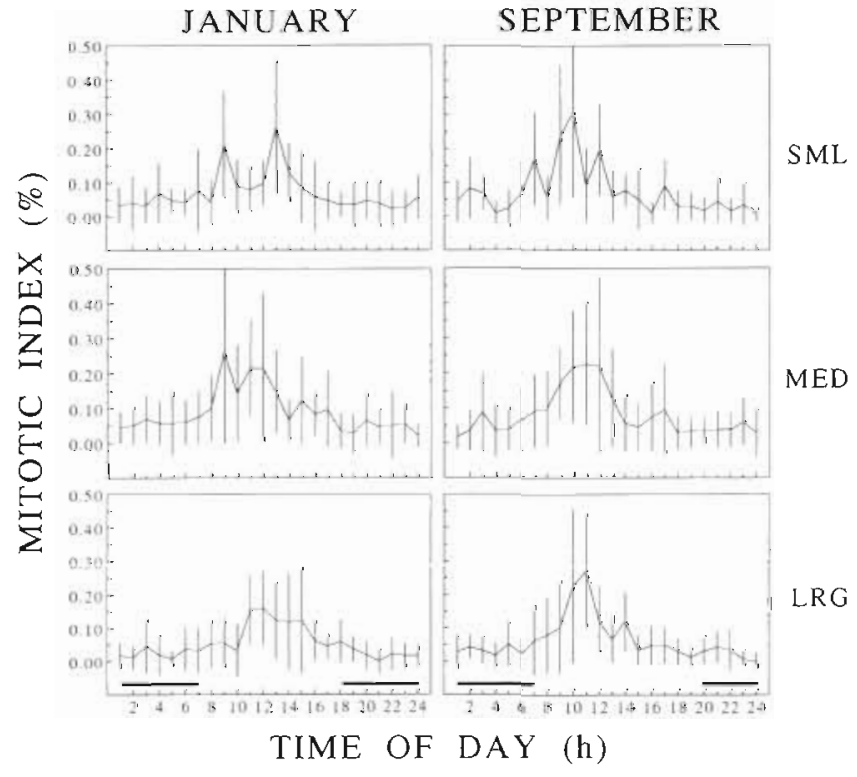

Fig. 3. Symbiodinium microadriaticum and Cassiopea xamachana. Diel mitotic index of zooxanthellae within C. xamachana as a function of jellyfish size (small: SML, medium: MED, and large: LRG) and season. Sample sires for each hour, regardless of season, for SML, MED, and LRG were 10 , 16 , and 10, respectively. Error bars show \pm SD. Bell diameter $(\mathrm{cm}, \bar{x} \pm \mathrm{SD})$ of each size class, regardless of season, was: Small $4.0 \pm 1.1$; Medium, $8.0 \pm 0.8$; Large, $13.0 \pm 2.2$. Horizontal lines denote occurrence of night

growth rate $(\mu)$, regardless of season and jellyfish size, was $0.0023 \mathrm{~d}^{-1}$.

Photosynthesis. Daily gross photosynthesis, normalized to cell density, protein, and chl $a$, is shown in Fig. 4. Cell- and protein-specific photosynthesis during September were significantly higher than during January (Fig. 4A, B) and showed a significant hostsize-specific relationship, with the photosynthesis of smaller jellyfish being significantly higher than that of larger individuals. The lower January rates, in contrast, exhibited no significant host size relationship (regression, $\mathrm{p}>0.05$ ) and averaged $( \pm \mathrm{SD}, \mathrm{n}=27$ )

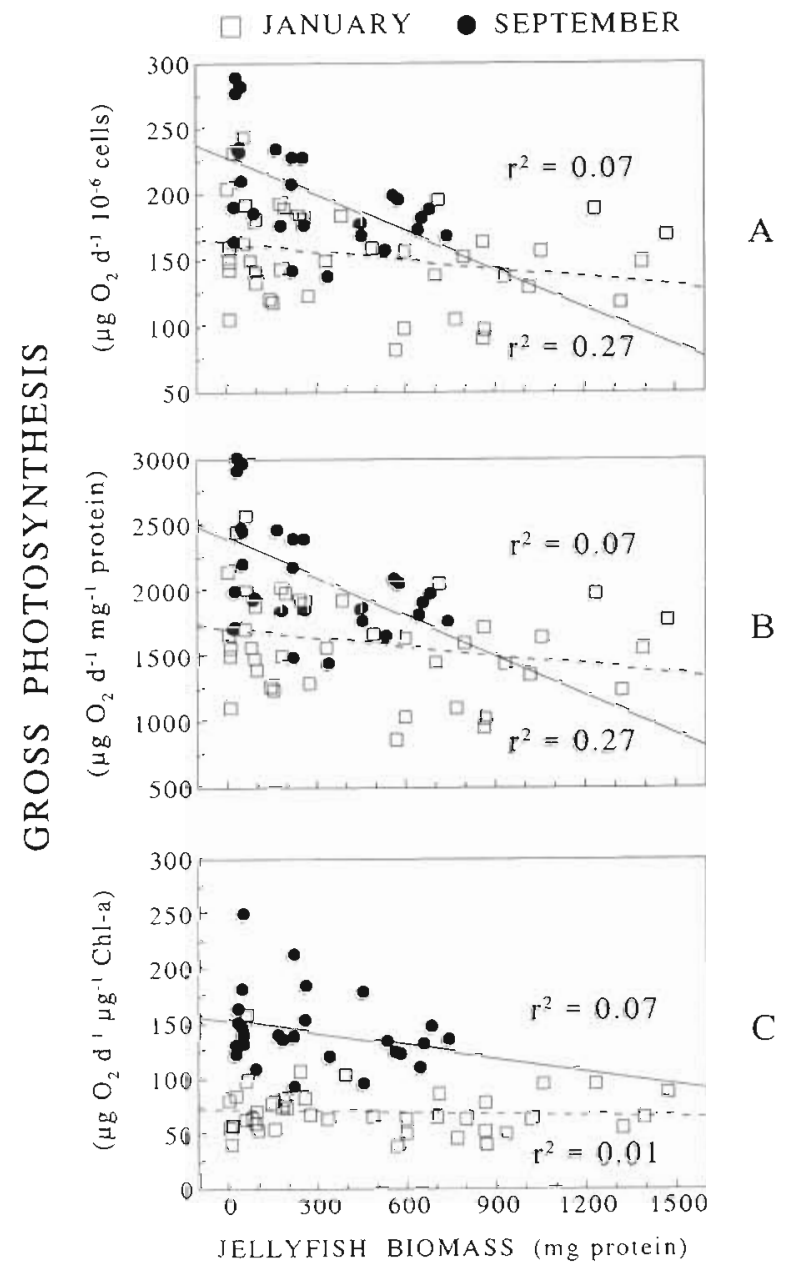

Fig. 4. Symbiodinium microadriaticum and Cassiopea xamachana. Gross photosynthesis $\left(P_{\mathrm{g}}\right)$ of zooxanthellae within $C$. xamachana as a function of jellyfish size and season. Best-fit curve for the relationship between gross photosynthesis and host biomass is linear regression. (A) Density; for January $\mathrm{r}^{2}=$ 0.07, for September $P_{\mathrm{g}}=-0.10$ (Biomass) $+228.41, \mathrm{r}^{2}=0.27$. (B) Protein; for January $\mathrm{r}^{2}=0.07$, for September $P_{\mathrm{g}}=$

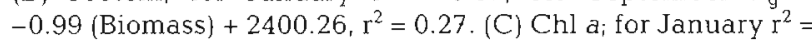
0.01 , for September $r^{2}=0.07$. Regression profiles where regression equations are given display slopes significantly different from zero. Sample sizes for January and September were 41 and 27 , respectively 

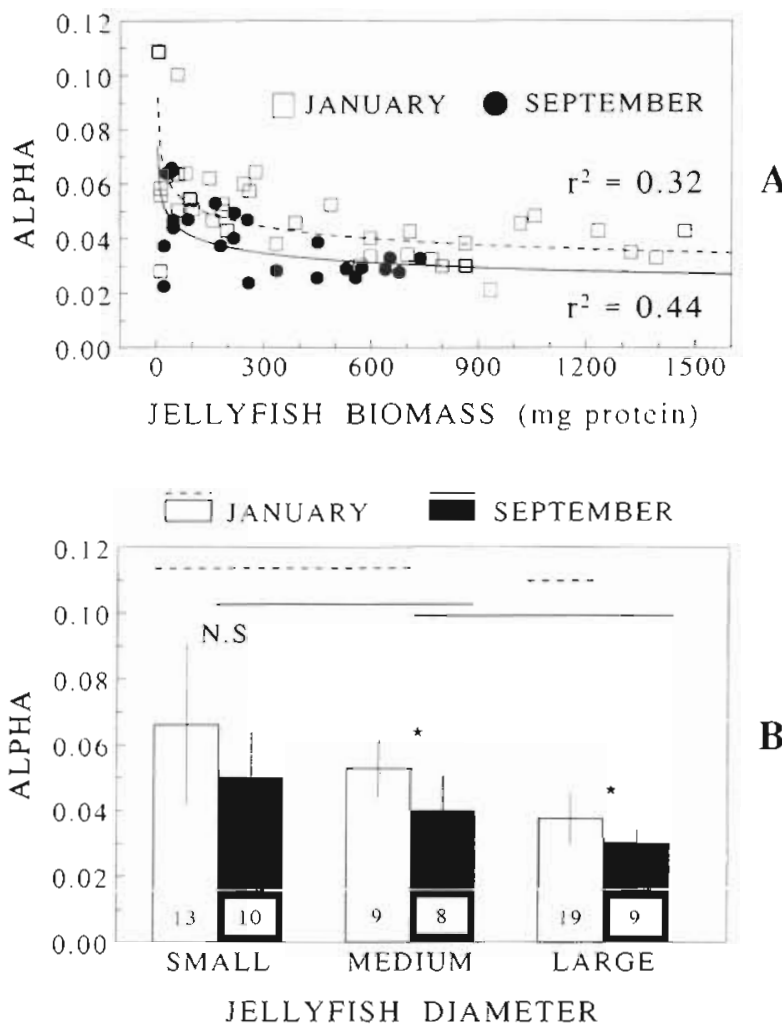

Fig. 5. Symbiodinium microadriaticum and Cassioped xamachana. Photosynthetic efficiencies $(\alpha)$ of zooxanthellae within C. xamachana as a function of jellyfish size and season. Best-fit curve for the relationship between $\alpha$ and host biomass (A) is a power function: January $\alpha=0.08$ (Biomass) $)^{-0.15}, \mathrm{r}^{2}=$ 0.32 ; September $\alpha=0.10$ (Biomass) $^{-0.15}, r^{2}=0.44$. For the relationship between $\alpha$ and host bell diameter (B) horizontal lines connect $\alpha$ values that are not signuficantly different (Tukey, $p>0.05$ ), and lines at different levels signify values that are significantly different (Tukey, $p<0.05$ ). Student's $t$-test: ns, not significant; $" p<0.05$. Error bars show $\pm S D$. Values within bars represent sample size. Bell diameter $(\mathrm{cm}, \bar{x} \pm \mathrm{SD})$ of each size class, regardless of season, was: Smal.l, $4.0 \pm 1.1$; Medium, $8.0 \pm 0.8 ;$ Large, $13.0 \pm 2.2$

$152.64 \pm 36.57 \mu \mathrm{g} \mathrm{O}_{2} \mathrm{~d}^{-1} \times 10^{-6}$ cells and $1604.01 \pm$ $384.26 \mu \mathrm{g} \mathrm{O}_{2} \mathrm{~d}^{-1} \mathrm{mg}^{-1}$ protein, respectively. Chlorophyll-specific photosynthesis during September was also significantly higher than photosynthesis during January (Fig. 4C). However, neither January nor September photosynthetic rates related to jellyfish size. The average $( \pm S D)$ January and September photosynthetic rates were $70.69( \pm 21.93, \mathrm{n}=27)$ and $142.35( \pm 34.43, \mathrm{n}=40) \mu \mathrm{g} \mathrm{O}_{2} \mathrm{~d}^{-1} \mu \mathrm{g}^{-1}$ chl $a$, respectively.

January-acclimated jellyfish displayed significantly higher photosynthetic efficiencies $(\alpha)$ (ANCOVA, $p<$ 0.01) than their counterparts during September (Fig. 5A). Jellyfish size-specific $\alpha$ displayed both seasonal and size dependent differences (Fig. 5B). In all

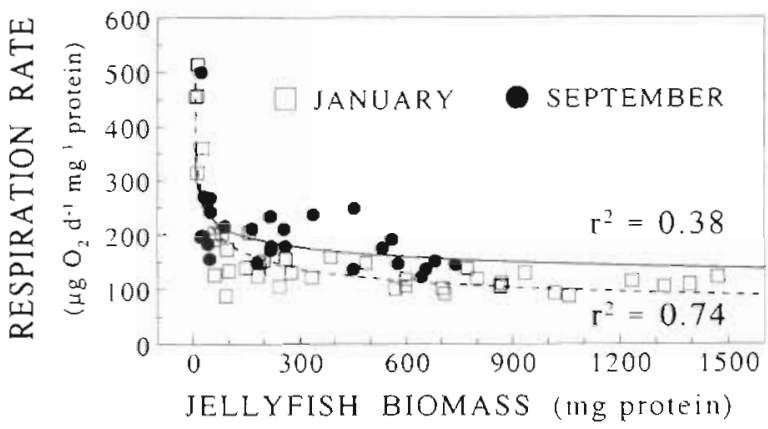

A

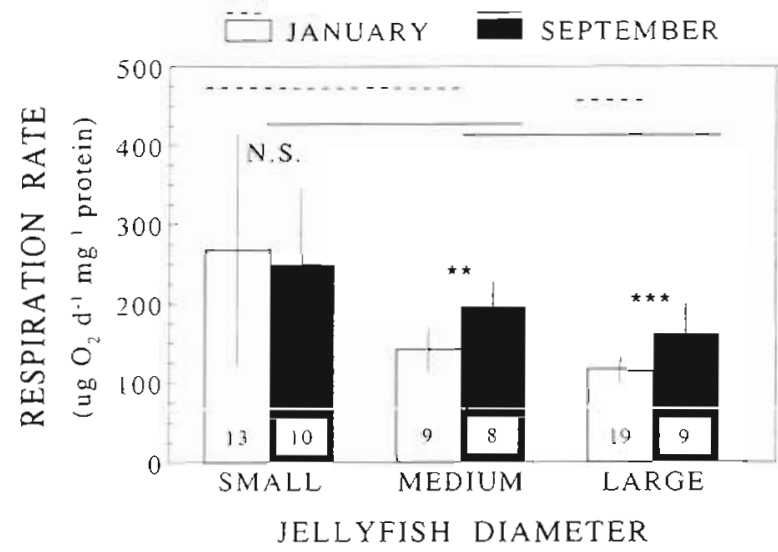

$\mathrm{B}$

Fig. 6. Cassiopea xamachana. Respiration rate of C. xamachana as a function of jellyfish size and season. Best-fit curve for the relationship between jellyfish respiration and biomass (A) is a power function: January resp. $=607.91$ (Biomass) $^{-025}$. $\mathrm{r}^{2}=0.74$; September resp. $=409.75$ (Biomass) ${ }^{0.15}, \mathrm{r}^{2}=0.38$. For the relationship between respiration and host bell diameter (B) horizontal lines connect respiration rates that are not significantly different (Tukey, $p>0.05$ ), and lines at different levels signify rates that are significantly different. (Tukey, $p<$ 0.05 ). Student's $t$-test: $n s$, not significant; $\cdots p<0.01 ; \cdots p<$ 0.001 . Error bars show $\pm \mathrm{SD}$. Values within bars represent sample size. Bell diameter ( $\mathrm{cm}, \bar{x} \pm \mathrm{SD}$ ) of each size class, regardless of season, was: Small, $4.0 \pm 1.1$; Medium, $8.0 \pm 0.8$; Large, $13.0 \pm 2.2$

cases, average January a were higher than September $\alpha$ although they were only significantly higher for medium and large jellyfish. Regardless of season, small jellyfish showed significantly higher $\alpha$ than large jellyfish.

\section{Jellyfish respiration}

Jellyfish respiration rates during September were significantly higher (ANCOVA, $\mathrm{p}<0.01$ ) than during January (Fig. 6A), particularly for medium and large jellyfish (Fig. 6B). Regardless of season, smaller jellyfish displayed significantly higher respiration rates than larger individuals. 




Fig. 7 Cassiopea xamachana. Daily carbon budget parameters of C. xamachana as a function of jellyfish size and season. Bestfit curves for the relationship between carbon budget parameter and jellyfish biomass are linear regression. (A) Net photosynthesis $\left(P_{n}\right)$ : January $P_{n}=0.054$ (Biomass) $+1.64, \mathrm{r}^{2}=0.92$; September $P_{\mathrm{n}}=0.074$ (Biomass) $+2.49, \mathrm{r}^{2}=0.96$. (B) Algal carbon-specific growth rate $\left(C_{\mu}\right)$ : January $C_{\mu}=0.00032$ (Biomass) $+0.011, r^{2}=0.97$; September $C_{\mu}=0.00027$ (Biomass) $+0.0047, r^{2}=0.98$. (C) Potentially translocated carbon $\left(C_{1}\right)$ : January $C_{1}=0.054$ (Biomass) $+1.63, r^{2}=0.92 ;$ September $C_{t}=0.073$ (Biomass) $+2.49, r^{2}=$ 0.96. (D) Animal respiration $\left(R_{\mathrm{a}}\right)$ : January $R_{\mathrm{a}}=0.032$ (Biomass) $+1.38, \mathrm{r}^{2}=097$; September $R_{\mathrm{d}}=0.043($ Biomass $)+1.94, \mathrm{r}^{2}=0.90$. (E) Available translocated carbon in excess of that utilized for animal respiration $\left(C_{\text {avail }}\right): C_{\text {avall }}=0.022(B i o m a s s)+1.09, r^{\prime \prime}=0.63$. (F) Potential carbon contribution of zooxanthellae towards the animal's respiratory requirements (CZAR): CZAR = 0.0050 (Biomass) $+171.19, r^{2}=0.001$. Sample sizes for January and September were 41 and 27, respectively

\section{Carbon budgets}

Daily net photosynthesis $\left(P_{n}\right)$, algal carbon-specific growth rate $\left(C_{\mu}\right)$, translocated carbon $\left(C_{1}\right)$, animal respiration $\left(R_{\mathrm{a}}\right)$, carbon available for host growth $\left(\mathrm{C}_{\text {aval }}\right)$, and CZAR are presented in Fig. 7. Algal $P_{\mathrm{n}}$ per jellyfish showed a direct relationship (ANCOVA, $p<0.001$ ) with jellyfish biomass (Fig 7A), with September rates significantly higher (ANCOVA, $p<0.001$ ) than in January (Fig. 7A). $C_{\mu}$ also displayed a direct relationship (ANCOVA, $\mathrm{p}<0.001$ ) with jellyfish biomass (Fig. $7 \mathrm{~B})$. However, January $C_{\mu}$ was significantly higher (ANCOVA, $p<0.05$ ) than September $C_{\mu}$. The calculated $\mathrm{C}_{1}\left(\right.$ i.e. $P_{\mathrm{n}}-\mathrm{C}_{\mu}$ ) also showed a direct relationship
(ANCOVA, $\mathrm{p}<0.001$ ) with jellyfish size (Fig. 7C) and, as for $P_{n}$, September $C_{t}$ rates were significantly higher (ANCOVA, $\mathrm{p}<0.05$ ) than January $\mathrm{C}_{1}$ rates.

Host $R_{a}$ was directly related (ANCOVA, $p<0.05$ ) to biomass (Fig. 7D) with $R_{\mathrm{a}}$ during September being significantly higher (ANCOVA, $p<0.01$ ) than in January. Like the other parameters, $C_{\text {avail }}$ was also directly related (ANCOVA, $\mathrm{p}<0.05$ ) to jellyfish biomass (Fig, 7E); however, there was no significant difference (ANCOVA, $p>$ $0.05)$ between January and September values. In contrast to the other carbon budget parameters, CZAR did not show a significant trend (ANCOVA, $p>0.05$ ) with either season or jellyfish size (Fig. $7 F$ ). The average $( \pm \mathrm{SD})$ CZAR for all jellyfish was $169.2 \%( \pm 65.2, \mathrm{n}=68)$. 
The distribution of carbon for an average Cassiopea medusa ( $\leq 800 \mathrm{mg}$ protein) acclimated to January or September conditions is shown in Fig. 8A, B, respectively. With the exception of $C_{\mu}$ carbon budget parameters (either estimated or directly measured) were between 39 and $48 \%$ higher for September- than January-acclimated jellyfish. In contrast, January $\mathrm{C}_{\mu}$ estimates were $20 \%$ higher than those in September.

\section{DISCUSSION}

The principal conclusion of this study concerns the definitive influence of seasonal environmental para-

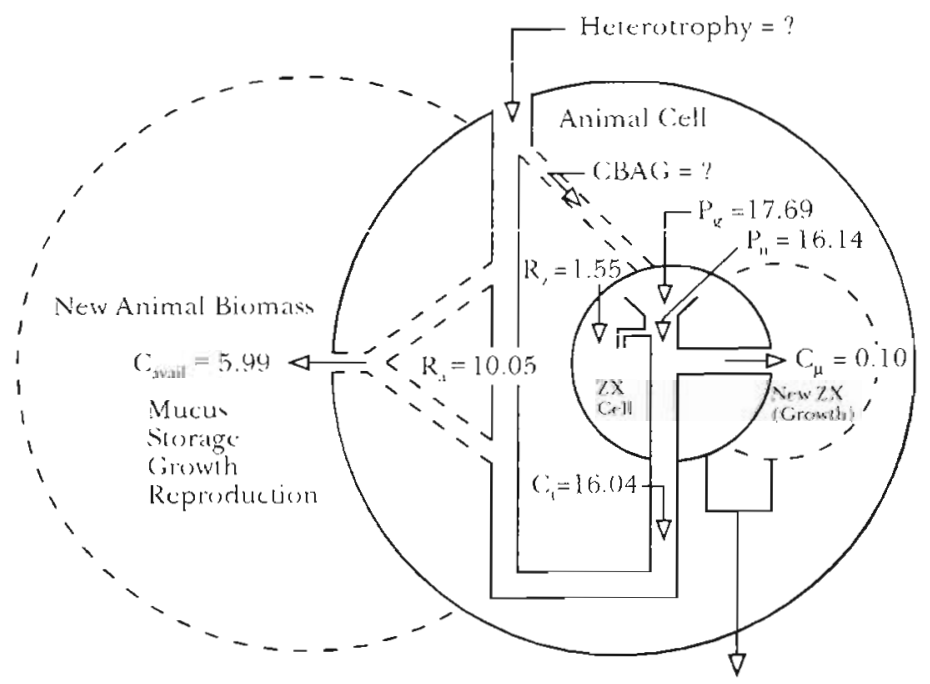

A. January Cassiopea xamachana

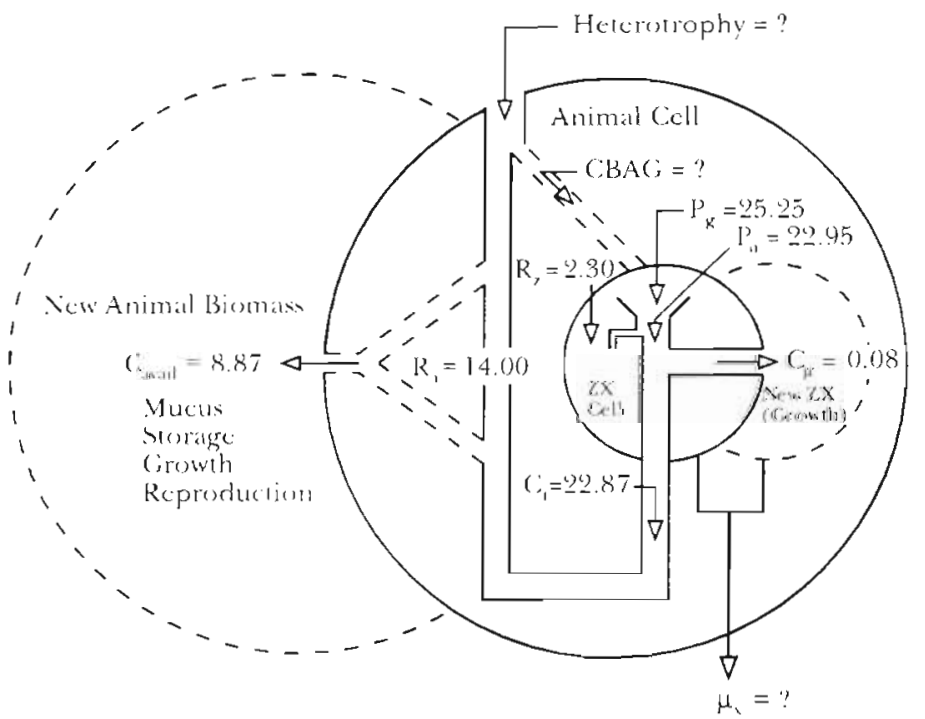

B. Scptember Cassiopea xamachana meters on both the photobiology and basic physiological aspects of algal-cnidarian symbioses. Both the photosynthetic (and resultant carbon budgets) and metabolic rates of Cassiopea xamachana are seasonally dependent, with higher rates occurring during September (summer) than January (winter), and are contingent on both light and thermal regimes. Winteracclimated symbionts photoadapt to reduced light conditions by increasing their internal pools of chlorophyll and becoming photosynthetically more efficient. However, these compensatory mechanisms are not enough to enhance photosynthetic rates to the levels observed during the summer. Such seasonally dependent physiological effects emphasize the requirement for seasonal investigations of algal-cnidarian symbioses in order to comprehend the ecological physiology and photobiology of the symbiotic association on an annual cycle.

\section{Algal parameters}

Cell size. A shift in algal cell size occurred as a function of season for Cassiopea xamachana, with medusae acclimated to 'winter' environmental conditions in the subtropical Florida Keys harboring larger-sized zooxanthellae $(9.08 \mu \mathrm{m}$ diameter) than jellyfish acclimated to summer conditions (8.64 $\mu \mathrm{m}$ diameter). Whether this phenomenon is an adaptation to environmental conditions or is directly regulated by the jellyfish host is not known, but it seems reasonable to posit that larger algal size may increase lightgathering efficiency.

Muscatine et al. (1986) reported an average cell diameter for zooxanthellae from small and large Mastigias sp, of 9.85 and $8.25 \mu \mathrm{m}$, respectively, while Kremer et al. (1990) reported a diameter of $8.9 \mu \mathrm{m}$ from Linuche unguiculata. These values are similar to those we measured for zooxanthellae from Cassiopea xamachana.

Fig. 8. Symbiodinium microadriaticum and Cassiopea xamachana. Average carbon fluxes for zooxanthellae from C. xamachana during (A) January and (B) September. Values are given as $\mathrm{mg} \mathrm{C} \mathrm{d}^{-1}$ for an average sized jellyfish which is $\leq 800 \mathrm{mg}$ protein. $P_{\mathrm{g}}$ and $P_{\mathrm{n}}$ are gross and net photosynthesis, respectively; $R_{z}$ and $R_{a}$ are algal and animal respiration, respectively; $C_{\mu}$ is the carbonspecific growth rate; $\mathrm{C}_{t}$ is the carbon translocated to the host; $\mu_{\mathrm{x}}$ is expelled algae; $\mathrm{C}_{\text {avail }}$ is the carbon available to the animal for mucus production, storage products, growth, and reproduction; CBAG is carbon back-translocated from the animal to the algae. Sample sizes for January and September were 31 and 27, respectively 
Chlorophyll. Vodenichar (1995) reported an average symbiont chl a content of approximately $1.0 \mathrm{pg} \mathrm{cell}^{-1}$ during summer conditions, which is lower than our values of $1.45 \mathrm{pg} \mathrm{cell}^{-1}$ for September zooxanthellae. The average algal chl a of zooxanthellae (during January) from Cassiopea xamachana (2.21 $\left.\mathrm{pg} \mathrm{cell}^{-1}\right)$ was similar to the 2.1 and $2.0 \mathrm{pg}$ cell $^{-1}$ reported by Kremer et al. (1990) and Wilkerson \& Kremer (1992) for Linuche unguiculata, and the $2.0 \mathrm{pg} \mathrm{cell-1}$ for Mastigias sp. reported by McCloskey et al. (1994). Likewise, the mean chl a:chl c ratio for algae in C. xamachana (3.37) was similar to the average ratios for algae from $L$. unguiculata (3.23).

In Cassiopea xamachana, the zooxanthella chlorophyll content during January was 1.5 times higher than for algae during September. Since both the daylength and light intensities were significantly lower during January than in September, these differences in irradiance levels may be the reason winter-acclimated zooxanthellae photoactively increase their internal pools of chlorophyll, as described for both symbiotic and free-living dinoflagellates (Richardson et al. 1983, Prezelin 1987). Alternatively, there may just be an increase in symbiont chlorophyll content concomitant with larger cell volumes.

Density. Vodenichar (1995) showed an average algal density of approximately $4.5 \times 10^{6}$ cells g ${ }^{-1}$ ww for Cassiopea xamachana ranging in size from 1 to $10 \mathrm{~cm}$ be!l diameter. When the cell densities from jellyfish in our study were normalized to $\mathrm{g} w \mathrm{w}$, the average value, regardless of season, was $9.6 \times 10^{6}$ cells $\mathrm{g}^{-1} \mathrm{ww}$, which is double the estimates of Vodenichar (1995). Why the medusae in our study contained twice the amount of algal symbionts contained in the jellyfish in Vodenichar's (1995) work remains a mystery. Perhaps experimental protocol or microhabitat differences between the 2 study sites are responsible, or possibly different algal taxa are involved. The jellyfish from the Vodenichar (1995) study were collected between June and September at Buttonwood Sound, Key Largo (FL, USA), whereas the medusae in this study were collected from Little Conch Key, Marathon, approximately $103 \mathrm{~km}$ further south. Vodenichar (1995) also brought the medusae into the laboratory for experimental manipulation, and the resultant handling may have caused algal expulsion, whereas medusae in our study were maintained in situ with minimal handling prior to estimation of algal densities.

In contrast to Cassiopea xamachana, the average algal density of Linuche unguiculata was $4.5 \times 10^{6}$ cells $\mathrm{mg}^{-1}$ protein (Kremer et al. 1990), which is 1.7 times greater than the algal density of $2.68 \times 10^{6}$ cells $\mathrm{mg}^{-1}$ protein for small-sized C. xamachana. Muscatine et al. (1986) reported that Mastigias sp. algal density was not a function of jellyfish size and calculated an average value of $2.8 \times 10^{6}$ cells $\mathrm{mg}^{-1}$ protein. This is almost identical to the algal density of small-sized C. xamachana but is 1.7 times higher than that for mediumsized medusae. Clearly there are significant differences as to how different species of symbiotic jellyfish maintain their complement of zooxanthella symbionts with respect to body size, but there are no obvious patterns or trends yet evident among the 3 species for which we have comparative data.

Regulation of algal symbionts by Cassiopea xamachana seems to occur primarily by host digestion of algae and by expulsion into the environment. Fitt \& Trench (1983) showed that heat-killed algae which underwent phagocytosis were susceptible to lysosomal attack by acid phosphatase. This suggests that endosymbiotic algae that become senescent, for whatever reason, may be consumed by the host through phagocytocis. Individual jellyfish, maintained in buckets with seawater, secreted mucus bands containing many zooxanthellae (authors' pers. obs.), although the expelled zooxanthella numbers were not quantified. Whether C. xamachana expels zooxanthellae continuously, at times when internal pools of zooxanthellae become too high or when the animal host is stressed, is not currently known. Like C. xamachana, large-sized Mastigias sp. seems to regulate algal populations (Muscatine et al. 1986) by expulsion or digestion. However, in smaller-sized Mastigias on. (Muscatine et al. 1986), algal populations may increase by transiently increasing the algal-specific growth rate $(\mu)$. Whether zooxanthellae within small-sized $C$. xamachana employ such methods for regulating algal population is not known.

Biomass: carbon, nitrogen, and protein. When biomass-related parameters of various jellyfish zooxanthellae are compared, Cassiopea xamachana zooxanthellae are similar to most others, with some notable exceptions. The carbon content of zooxanthellae from

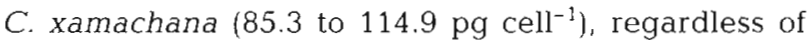
season, is higher than values previously reported for other jellyfish. Kremer et al. (1990) and Muscatine et al. (1986) reported values of 58.0 and $56.1 \mathrm{pg} \mathrm{C} \mathrm{cell-1}$ for zooxanthellae from Linuche unguiculata and Mastigias sp., respectively. This carbon content difference between C. xamachana, L. unguiculata, and Mastigias sp. may be a by-product of the methods utilized to obtain cellular carbon. Algal carbon in our work was obtained from empirical $\mathrm{C}: \mathrm{N}$ measurements of isolated algae, whereas the values of Muscatine et al. (1986) and Kremer et al. (1990) were derived from algal volumes applied to the regression equation of Strathmann (1967). If the cell volumes of zooxanthellae from $C$. xamachana are used to estimate carbon content via the equation of Strathmann (1967), the values obtained are 55.0 and $62.2 \mathrm{pg} \mathrm{C} \mathrm{Cell}^{-1}$ and bracket the 
numbers reported by Muscatine et al. (1986) and Kremer et al. (1990).

Kremer et al. (1990) and Wilkerson \& Kremer (1992) reported that algae from Linuche unguiculata have a nitrogen content of 13.3 to $15.7 \mathrm{pg} \mathrm{N}$ cell ${ }^{-1}$, which is very similar to values reported in this study. The protein content of zooxanthellae from Cassiopea xamachana is 2.5 times higher than that for algae from Mastigias sp., which have an average of $36.3 \mathrm{pg}$ protein cell ${ }^{-1}$ (Muscatine et al, 1986). Muscatine et al. (1986) and Kremer et al. (1990) reported C:N values of 9.7 and 6.2 , respectively, which are also similar to the C:N ratio of zooxanthellae from C.xamachana. In summary, the biomass parameters of Symbiodinium microadriaticum within C. xamachana are nearly identical to those of zooxanthellae from other jellyfish.

Mitotic index and algal growth. Wilkerson et al. (1983) reported that zooxanthellae from Mastigias sp. display a phased, diel cell division profile (sensu McDuff \& Chisholm 1982). Wilkerson et al. (1983) attributed such a phased MI to exposure of the algal symbionts to a $2 \mathrm{~h}$ pulse of ammonium at niqht. Other cnidarians exhibiting phased symbiont division include the corals Seriatopora hystrix (Hoegh-Guldberg \& Smith 1989), Stylophora pistillata, Fungia repanda, and Pocillopora damicornis (Smith \& Hoegh-Guldberg 1987). Clifford \& Blanquet (1991) also reported that zooxanthellae extracted from Cassiopea xamachana and cultured with a $14 \mathrm{~h}$ light: $10 \mathrm{~h}$ dark cycle display a diel pattern of cell motility, with phased division occurring during the latter part of the dark period.

As we have shown, zooxanthellae in Cassiopea xamachana also appear to display a phased algal MI. In contrast to the findings of Clifford \& Blanquet (1991), the zooxanthellae within C. xamachana demonstrated a daytime phased division pattern between 09:00 and 12:00 h. Why in vitro phased division occurs in the dark and in hospite phased division occurs during daytime is not known, but one possibility may be that some host-derived fraction regulates algal cell division. Precedence for such regulation is provided by Carroll \& Blanquet (1984a, b) and Blanquet et al. (1988) for alanine uptake and by McDermott \& Blanquet (1991) for glucose uptake by zooxanthellae via inhibitory fractions derived from host homogenates.

Unlike Mastigias sp., Cassiopea xamachana does not exhibit diel migration but remains stationary on the sediment-water interface. It may be that carbon and nitrogen from bacterial metabolism at the sediment surface or tentacles (Schiller \& Herndl 1989) or from mangrove litter decomposition (Lugo \& Snedaker 1974, Fell et al. 1975, Newell et al. 1984, Robertson. 1988, Mackey \& Smai. 1996) are transepidermally absorbed by $C$. xamachana as are various amino acids in other soft-bodied invertebrates (Schlichter 1984, DeFreese \& Clark 1991, Preston 1993) and are subsequently utilized by the algae to support phased division. Such uptake of carbon from decomposing mangrove litter is also expected to be higher during the summer than winter due to higher decomposition rates that occur during the summer season (Mackey \& Smail 1996). Alternatively, inorganic nitrogen in the form of ammonium may also be directly absorbed transepidermally from the water, much as for Mastigias sp. (Mus catine \& Marian 1982) or Linuche unguiculata (Wilkerson \& Kremer 1992), and from the sediment, since the concentrations of these nutrients are higher inshore than offshore (Szmant \& Forrester 1996). Similarly, dissolved organic matter may also be absorbed and used as a food source, as is the case for Heteroxenia fuscescens (Schlichter 1982a, b, Schlichter et al. 1983, 1984)

Alternatively, high levels of predation by the host on zooplankton could support phased algal division. Cassiopea xamachana is a rapacious predator of Artemia nauplii during feeding studies in aquaria (E.A.V ners. obs.). Support for prey-enhanced algal symbiont growth is provided by McAuley \& Cook (1994), who reported that zooxanthellae in starved colonies of the hydroid Myrionema amboinense show an MI of 3.9\%, whereas in colonies fed Artemia nauplii, the $\mathrm{MI}$ increased by a factor of 2.6 to $10.08 \%$. McAuley \& Cook (1994) also provide evidence that external nitrogen sources directly influence zooxanthella division rates. Other studies correlating increased zooxanthellae cell division with host feeding include Fitt \& Cook (1990) on $M$. amboinense and Cook et al. (1988) on the anemone Aiptasia pallida.

From the algal-specific in hospite growth rate value $(\mu)$ of $0.0023 \mathrm{~d}^{-1}$ for zooxanthellae in Cassiopea xamachana, one can compute a doubling time for the symbiont population of $301 \mathrm{~d}$ using the equation of Wilkerson et al. [1983; $\left.\mathrm{D}_{1}=(\ln 2) \mu^{-1}\right]$. With such Iow growth rates and long doubling times, it is unlikely overgrowth by the symbionts poses a threat to the host. The average $\mu$ of zooxanthellae from Mastigias sp. and Linuche unguiculata is $0.10 \mathrm{~d}^{-1}$ and 0.02 to $0.04 \mathrm{~d}^{-1}$, respectively (Wilkerson et al. 1983, Kremer et al. 1990, McCloskey et al. 1994). However, these relatively high growth rates are based on a duration of cytokinesis of $11.0 \mathrm{~h}$ (Wilkerson et al. 1983) whereas the growth rate estimate of zooxanthellae from C. xamachana does not utilize this number since the diel division rates are phased. The $\mu$ of $0.0023 \mathrm{~d}^{-1}$ for symbionts from C. xamachana is closer to those measured for zooxanthellae from the corals Pocillopora eydouxi $\left(0.0017 \mathrm{~d}^{-1}\right.$, Davies 1984) and Porites porites (0.0023 to $0.0028 \mathrm{~d}^{-1}$, Edmunds \& Davies 1986 , 1989) and the temperate anemone Anthopleura elegantissima (0.0029 $\mathrm{d}^{-1}$, Verde \& McCloskey 1996). 
Table 3. Mean photosynthesis versus irradiance (P-I) parameters of 3 jellyfish, Cassiopea xamachana, Mastigias sp. and Linuche unguiculata. The P-I data of Mastigias sp. and L. unguiculata were obtained from McCloskey et al. (1994) and Kremer et al. (1990), respectively. The C.xamachana data were obtained from small and medium sized jellyfish from both January and September months which corresponded to the sizes of Mastigias sp. and L. unguiculata. C:M = C. xamachana:Mastigias sp. ratio. $C: L=C$. xamachana: $L$. unguiculata ratio. na: not available

\begin{tabular}{|c|c|c|c|c|c|}
\hline P-I & Cassiopea & Mastigias & Linuche & $\mathrm{C}: \mathrm{M}$ & $C: L$ \\
\hline$\alpha$ & 0.054 & 0.140 & $0.189^{\mathrm{b}}$ & 0.39 & 0.29 \\
\hline$I_{\mathrm{k}}$ & 413.9 & 133.0 & $200-300$ & 3.11 & $1.4-2.1$ \\
\hline$I_{\mathrm{opt}}$ & 1497.2 & 307.0 & na & 4.88 & - \\
\hline$P_{n}^{\circ} \max$ & 20.8 & 16.9 & $9.5^{5}$ & 1.23 & 2.19 \\
\hline \multicolumn{6}{|c|}{ 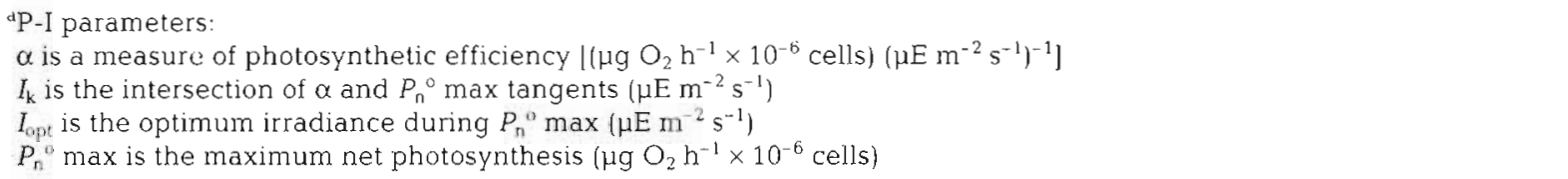 } \\
\hline \multicolumn{6}{|c|}{  } \\
\hline \multicolumn{6}{|c|}{$\begin{array}{l}\text { cWhere } P_{\mathrm{n}}^{0} \mathrm{max}=4.5 \mathrm{mg} \mathrm{O} \mathrm{h}^{-1} \mathrm{mg}^{-1} \mathrm{chl} a \text { and chl a cell }{ }^{-1}=2.1 \mathrm{pg}\left(1.0 \mathrm{mg} \text { chl } \mathrm{a}=476.2 \times 10^{6} \text { cells }\right) \text {. Therefore, } \\
\left(4.5 \mathrm{mg} \mathrm{O}_{2} \mathrm{~h}^{-1} \mathrm{mg}^{-1} \mathrm{chl} \text { a) }\left(476.2 \times 10^{6} \text { cells }\right)^{-1}=9.5\left(\mu \mathrm{g} \mathrm{O}_{2} \mathrm{~h}^{-1} \times 10^{-6} \mathrm{cells}\right)\right.\end{array}$} \\
\hline
\end{tabular}

The determination of the MI only from symbionts specifically located within the tentacles may be justifiably questioned, since the algal MI from the tentacles of some cridarians is elevated compared to the rest of the organism. Muller-Parker (1987) reported an alyal Mil from the tentacles of Aiptasia pulchella to be 1.5 times higher than the MI from the anemone column. In contrast, a tentacle-based MI for either zooxanthellae or zoochlorellae from Anthopleura elegantissima is similar to the MI of symbionts from the whole anemone (E.A.V. unpubl. data). For Cassiopea xamachana, we deemed it appropriate to determine algal growth rates from tentacle-derived symbionts because the majority of algae $(75 \%)$ were located within the tentacles and this value was similar to the $70 \%$ reported for zooxanthellae in Mastigias sp. (Muscatine \& Marian 1982). These tentacle snips also permitted time-course evaluations of MI changes in single jellyfish. For these reasons, we have used the more conveniently-obtained MI values from tentacle snips.

Photosynthesis. Although their photosynthesis-irradiance parameters differ (Table 3) the photosynthetic rates of Cassiopea xamachana and other symbiotic jellyfish, such as Mastigias sp., Linuche unguiculata, and Cassiopea andromeda, are very similar (Table 4). Not surprisingly, a strong seasonal influence on photosynthetic rates takes place. Since light intensity, light duration, and water temperature are significantly greater during September than during January, higher photosynthetic rates would be expected during September. If summer measurements were conducted during June (i.e. summer solstice), the summer photo- synthetic rates (and resultant carbon flux values) would be expected to be even higher than reported here for September. On the other hand, January-acclimated symbionts have significantly higher $\alpha$ and chlorophyll content, suggesting that these algae adapt to these lower light and temperature regimes by being more efficient at capturing incident light. Similar seasonal photosynthetic rates were reported by Barnes (1988) on the Great Barrier Reef (Davis Reef, Australia), where gross photosynthesis was more than $30 \%$ higher during August compared to December. When a $10 \%$ reduction in respiration during December was considered, the resultant net photosynthesis was higher by $45 \%$ (Barnes 1988). The conclusions of Barnes (1988) and those reported in this study underscore the necessity for seasonal studies on algalcnidarian symbioses.

When photosynthesis is examined as a function of jellyfish size, the highest rates occurred in smallersized individuals. This scaling of photosynthetic rates is due to the significantly higher algal densities and metabolic rates of smaller jellyfish, both of which promote elevated photosynthesis. Similar results were obtained by Fisher et al. (1985) from the giant clam Tridacna gigas and Vodenichar (1995) in Cassiopea xamachana in which both photosynthesis and respiration displayed an inverse relationship with animal size.

The reduction of photosynthetic rates with increasing jellyfish size during September may be due to algal shading, either from increased algal self-shading or from medusan pigmentation. The idea that algal selfshading plays a greater role in reducing photosynthesis than host pigmentation in Cassiopea xamachana is 
Table 4. Comparison of the average maximum gross photosynthetic rates of 4 tropical symbiotic jellyfish: Mastigias sp., Linuche unguiculata, Cassiopea andromeda, and Cassiopea xamachana. na: not available

\begin{tabular}{|c|c|c|c|}
\hline Jellyfish & $\begin{array}{c}P_{\mathrm{g}}{ }^{\circ} \max \\
\left(\mu \mathrm{O} \mathrm{O}_{2} h^{-1} \times 10^{-6} \text { cells }\right)\end{array}$ & $\begin{array}{c}P_{\mathrm{g}}^{0} \max \\
\left(\mu \mathrm{O}_{2} \mathrm{~h}^{-1} \mu \mathrm{g}^{-1} \mathrm{chl} a\right)\end{array}$ & Source \\
\hline $\begin{array}{l}\text { Mastigias sp. } \\
\text { Lake } \\
\text { Lagoon }\end{array}$ & $\begin{array}{l}17.6 \\
29.6\end{array}$ & $\begin{array}{r}8.8 \\
14.8\end{array}$ & McCloskey et al. $(1994)^{\mathrm{a}}$ \\
\hline Linuche unguiculata & 12.6 & 6.0 & Kremer et al. $(1990)^{a}$ \\
\hline Cassiopea andromeda & na & $3.7-4.2$ & Hofmann \& Kremer (1981) \\
\hline $\begin{array}{l}\text { Cassiopea xamachana } \\
\text { January } \\
\text { September }\end{array}$ & $\begin{array}{l}13.6 \\
15.8^{c}\end{array}$ & $\begin{array}{r}6.3 \\
11.1\end{array}$ & $\begin{array}{l}\text { Present study } \\
\text { Present study }\end{array}$ \\
\hline $\begin{array}{l}{ }^{\circ} \text { From Table } 7 \text { of } \mathrm{McCl} \\
{ }^{b} \text { From Table } 4 \text { of Krem } \\
\text { 'Based on a grand mea }\end{array}$ & $\begin{array}{l}(1994) \\
90) \\
\text { s of jellyfish size }\end{array}$ & & \\
\hline
\end{tabular}

supported by the work of Blanquet \& Phelan (1987). They found that the unique mesogleal polymeric qlycoprotein pigment 'Cassio Blue' in C. xamachana attenuated harmful solar radiation while permitting the penetration of photosynthetically active radiation. Consequently, in this instance, this particular host pigment does not significantly reduce algal photosynthesis

Since Cassiopea sp. are generally found in shallow depths (Drew 1972) ranging from $0.1 \mathrm{~m}$ (seagrass and mangrove beds) to $10 \mathrm{~m}$ (coral borrow pits, see Clark \& DeFreese 1987) in Florida, they are exposed to high light intensities and ultraviolet (UV) radiation. The symbiont photosynthetic rates are concomitantly higher without showing any photoinhibition effects (authors' unpubl. data) and these jellyfish may protect themselves from $\mathrm{O}_{2}$ toxicity by producing both superoxide dismutase (SOD) and catalase (Dykens 1984, Lesser 1989, Lesser \& Shick 1989a, b). Similarly, they would be expected to maintain elevated quantities of UV-absorbing compounds similar to those found within the mucus of Fungia fungites (Drollet et al. 1993) or mycosporine-like amino acids (MAAs) (Shick et al. 1992, 1995, Stochaj et al. 1994). Banaszak \& Trench $(1995 \mathrm{a}, \mathrm{b})$ described the effects of UV on $C$. xamachana and its symbionts. They showed that Symbiodinium microadriaticum from C. Xamachana synthesizes 3 MAAs (mycosporine-glycine, shinorine, and porphyra-334). These MAAs are subsequently translocated to the host and are used by the host to minimize deleterious UV effects. It is these environmentally driven physiological adaptations which have permitted this symbiotic association to thrive at high densities in shallow areas of the tropical and subtropical subtidal zone.

\section{Jellyfish respiration}

It is difficult to directly compare the respiration rates of Cassiopea xamachana with other jellyfish metabolic rates (Kremer et al. 1990, McCloskey et al. 1994) due to the problem of normalizing units and size variation. Small-sized jellyfish display higher mass-specific metabolic rates than larger individuals and this inverse scaling between animal size and metabolism is a wellknown biological phenomenon. Similar size-specific metabolic rates were reported by Vodenichar (1995) for C. Xamachana. September metabolism is much higher than that of January, and this is probably a simple consequence of elevated temperature effects since the average water temperature during September $\left(29.9^{\circ} \mathrm{C}\right)$ was significantly higher than for January $\left(24.2^{\circ} \mathrm{C}\right)$.

\section{Carbon budgets}

The individual carbon budget components usually displayed a direct relationship with jellyfish biomass, and the 3 components $P_{n}, C_{t}$ and $R_{a}$ are significantly higher during September due to higher water temperatures, light intensities, longer daylength, or a combination of all three. In contrast, January $C_{\mu}$ is significantly higher than the $C_{\mu}$ during September, which we believe is a direct consequence of the higher carbon per algal cell during January. The $\mathrm{C}_{\text {aval }}$ is the quantity of carbon available to the animal host for reproduction, storage, growth, mucus production, or the synthesis of a suite of important metabolites (such as SOD, catalase, MAA's, and peroxidase).

The potential contribution of algal carbon products to animal respiration (CZAR) showed no relationship 
with either season or jellyfish biomass. This is counterintuitive because $P_{n}, C_{\mu}$ and $C_{1}$ showed such a strong relationship with biomass. The explanation is that, since $R_{\mathrm{a}}$ is also directly related to biomass, CZAR values, regardless of season, are not correlated with jellyfish size. CZAR is an estimate of the integrated $P: R$ ratio; if net photosynthesis (minus algal carbon-specific growth) is greater than host respiration, then CZAR is greater than 1 (i.e. $100 \%$ ).

An average CZAR of $169 \%$ suggests that the zooxanthellae are potentially capable of providing all of the carbon necessary to support the respiration of the medusa, and Cassiopea xamachana may not require any external carbon sources. This value is similar to that reported for Linuche unguiculata $160 \%$, Kremer et al 1990) and for lagoon Mastigias sp. (143\%, McCloskey et al. 1994). A comparatively lower CZAR of $97 \%$ for lake Mastigias sp. was attributed to elevated host metabolism resulting from this morph's diel migration patterns (McCloskey et al. 1994). A CZA.R of $169 \%$ for C. xamachana may actually be a conservative estimate due to likely presence of a resident microbial fauna associated with the tentacular region of the medusa (sensu Schiller \& Herndl 1989, Hansson \& Norrman 1995). The combined bacterial respiration was not factored out of the calculation of the jellyfish respiration, which would overestimate host metabolism, and consequently, CZAR values wuuid be reduced in magnitude commensurate with the extent of microbial metabolism.

Vodenichar (1995) reported CZAR values of approximately $106 \%$ in medusae with a bell diameter greater than $6 \mathrm{~cm}$, whereas smaller-sized jellyfish showed CZAR values of approximately $73 \%$. Vodenichar (1995) suggested that these smaller medusae as well as symbiotic larvae and scyphistomae may require external carbon sources to meet their respiratory carbon requirements. In contrast to the CZAR estimates of Vodenichar (1995), we calculate an average CZAR $( \pm \mathrm{SD})$ value of $171 \%( \pm 88, \mathrm{n}=22)$ for medusae with a bell diameter less than $6 \mathrm{~cm}$. Because these 2 studies utilized decidedly different methods and equipment for measuring photosynthesis (with differing algal densities) and respiration, these differences undoubtedly contributed to the respective dissimilarities in CZAR estimates. Vodenichar (1995) measured both photosynthesis and respiration in a laboratory environment by taking $\mathrm{O}_{2}$ readings every $5 \mathrm{~min}$ for a total of $30 \mathrm{~min}$ at ambient light intensities above $800 \mu \mathrm{E} \mathrm{m}^{-2} \mathrm{~s}^{-1}$ and calculated CZAR assuming 8 h of saturated photosynthesis. We believe that our CZAR estimates of $171 \%$ are more accurate and realistic for medusae of this size since our measurements of both photosynthesis and respiration took place in situ over the course of $24 \mathrm{~h}$ at the site where abundant densities of Cassiopea xamachana were located.
Four parameters were not estimated or measured in this study of Cassiopea xamachana carbon budgets: CBAG, new animal growth, $\mu_{x}$ and heterotrophy. The potential for carbon to be back-translocated from the animal to the algae (CBAG, see Verde \& McCloskey $1996)$ is a remote possibility. Jellyfish growth rates are also an unknown variable and remain to be estimated. The carbon expelled from the association in the form of intact algal cells, $\mu_{x}$ (Hoegh-Guldberg et al, 1987, McCloskey et al. 1996), is also an unknown for C. xamachana. Heterotrophy represents the amount of carbon obtained from captured prey or dissolved organic carbon (DOC) directly absorbed by both the ectoderm and endoderm as previously discussed

Another source of carbon loss from this association is the quantity of mucus that can be released by Cassiopea xamachana. Between 40 and $60 \%$ of the daily carbon fixed by photosynthesis in the coral Acropora acuminata and Acropora formosa was released as mucus or DOC (Crossland 1980, Crossland et al. 1980a, b). Recently, Hansson \& Norman (1995) estimated that an average of $1.2 \mathrm{mg} \mathrm{C} \mathrm{d}^{-1}$ is released as DOC in the temperate jellyfish Aurelia aurita. Consequently, mucus production and loss from $C$. xamachana could be a significant carbon sink for this association. This excreted mucus is likely used to foster bacterial growth on the medusan tentacles (Hansson \& Norrman 1995), and this microbial population could be used dirertly or indirectly as a carbon resource as described by Schiller \& Herndl (1989) for several coral species.

Acknowledgements. This research was supported by a Walt Disney World Company grant and Houston Underwater Club SeaSpace Scholarship (to E.A.V.) and a National Science Foundation grant OCE-8303513 (to L.R.M.). We thank the staff of both The Living Seas, EPCOT, Walt Disney World Company and Conch Key Cottages for the use of boats and facilities and the Florida Department of Natural Resources for collecting permits. We express our gratefulness to $\mathrm{K}$. Clark for collecting jellyfish, W. Fitt for his pre-submission review of this manuscript and other remarks regarding Cassiopea, and $V$. Weis for an additional evaluation. We thank 3 anonymous reviewers for their critical comments; their suggestions greatly enhanced this manuscript. The help of A. Cleveland, K. McCloskey, and R. Verde during this project was much appreciated.

\section{LITERATURE CITED}

Balderston WL, Claus G (1969) A study of the symbiotic relationship between Symbiodinium microadriaticum Freudenthal, a zooxanthellae and the upside down jellyfish, Cassiopea sp. Nova Hedwigia 17:373-382

Banaszak AT, Trench RK (1995a) Effects of ultraviolet (UV) radiation on marine microalgal-invertebrate symbioses. I. Response of algal symbionts in culture and in hospite. J Exp Mar Biol Ecol 194:213-232

Banaszak AT, Trench RK (1995b) Effects of ultraviolet (UV) 
radiation on marine microalgal-invertebrate symbioses. If The synthesis of mycosporine-like amino acids in response to exposure to UV in Anthopleura elegantissima and Cassiopea xamachana. J Exp Mar Biol Ecol 194:233-250

Barnes DJ (1988) Seasonality in community productivity and calcification at Davies Reef, Central Great Barrier Reef Proc 6th Int Coral Reef Symp 2:521--527

Battey JF (1992) Carbon metabolism in zooxanthellae-coelenterate symbioses. In: Reisser W (ed) Algae and symbioses. Biopress Ltd, Bristol, p 153-187

Blanquet RS, Emanuel D, Murphy TA (1988) Suppression of exogenous alanine uptake in isolated zooxanthellae by cnidarian host homogenate fractions: species and symbiosis specificity. J Exp Mar Biol Ecol 117:1-8

Blanquet RS, Phelan MA (1987) An unusual blue mesogleal protein from the mangrove jellyfish Cassiopea xamachana. Mar Biol 94:423-430

Brewer RH, Feingold JS (1991) The effect of temperature on the benthic stages of Cyanea (Cnidaria: Scyphozoa), and their seasonal distribution in the Niantic River estuary, Connecticut. J Exp Mar Biol Ecol 152:49-60

Carroll S, Blanquet RS (1984a) Alanine uptake by isolated zooxanthellae of the mangrove jellyfish, Cassiopea xamachana. I. Transport mechanisms and utilization. Biol Bull 166:409-418

Carroll S, Blanquet RS (1984b) Alanine uptake by isolated zoovanthellae of the mangrove jollyfish, Cussiopea ram achana. II. Inhibition by host homogenate fraction. Biol Bull 166:419-426

Cates N (1975) Productivity and organic consumption in Cassiopea and Condylactis. J Exp Mar Biol Ecol 18:55-59

Cates N, McLaughlin JJA (1976) Differences of ammonia metabolism in symbiotic and aposymbiotic Condylactus and Cassiopea spp. J Exp Mar Biol Ecol 21:1-5

Clark KB, DeFreese DE (1987) Population ecology of caribbean ascoglossa (Mollusca: Opisthobranchia): a study of specialized algal herbivores. Am Malacol Bull 5: $259-280$

Clifford JM, Blanquet RS (1991) Effects of host homogenate on the motility of endozoic algae from Cassiopea xamachana. Am Zool 31:1-154

Cook CB, D'Elia CF, Muller-Parker G (1.988) Host feeding and nutrient sufficiency for zooxanthellae in the sea anemone Aiptasia pallida. Mar Biol 98:253-262

Crossland CJ (1980) Release of photosynthetically-derived organic carbon from a hermatypic coral, Acropora cf. acuminata. In: Schwemmler W, Schenk HEA (eds) Endosymbiosis and cell biology. Walter deGruyter, Berlin, p $163-172$

Crossland CJ, Barnes DJ, Borowitzka MA (1980b) Diurnal lipid and mucus production in the staghorn coral Acropora acuminata. Mar Biol 60:81-90

Crossland CJ, Barnes DJ, Cox T, Devereux M (1980a) Compartmentation and turnover of organic carbon in the staghorn coral Acropora formosa. Mar Biol 59:181-187

Davies PS (1984) The role of zooxanthellae in the nutritional energy requirements of Pocillopora eydouxi. Coral Reefs 2 $181-186$

Davies PS (1992) Endosymbiosis in marine cnidarians. In: John DM. Hawkins SJ, Price JH (eds) Plant-animal interactions in the marine benthos. Clarendon Press, Oxford, p 511-540

DeFreese DE, Clark KB (1991) Transepidermal uptake of dissolved free amino acids from seawater by three ascoglossan opisthobranchs. J Moliuscan Stud 57:65-74

Drew EA (1972) The biology and physiology of alga-invertebrate symbioses. I. Carbon fixation in Cassiopea sp. at
Aldabra Atoll. J Exp Mar Biol Ecol 9:65-69

Drollet JH, Glaziou P, Martin PM (1993) A study of mucus from the solitary coral Fungia fungites (Scleractinia: Fungiidae) in relation to photobiological UV adaptation. Mar Biol 115:263-266

Dykens JA (1984) Enzymic defense against oxygen toxicity in marine cnidarians containing endosymbiotic algae. Mar Biol Lett 5:291-301

Edmunds PJ, Davies PS (1986) An energy budget for Porites porites (Sclerartinia). Mar Biol 92:339-347

Edmunds PJ, Davies PS (1989) An energy budget for Porites porites (Scleractinia) growing in a stressed environment. Coral Reefs 8:37-43

Fell JW, Cefalu RC, Masters IM, Tallman AS (1975) Microbial activity in the mangrove (Rhizophora mangle) leaf detritus system. In: Walsh GE, Snedakar SC, Teas HJ (eds) Proc Int Symp Biology and Management of Mangroves (Honolulu, HI). Univ of Florida, Gainesville, p 661-679

Fisher CR, Fitt WK, Trench RK (1985) Photosynthesis and respiration in Tridacna gigas as a function of irradiance and size. Biol Bull 169:230-245

Filt WK Cook CB (1990) Some effects of host feeding on growth of zooxanthellae in the marine hydroid Myrionema amboinense in the laboratory and in nature. In: Nardon $\mathrm{P}$, Gianinazzi-Pearson V, Grenier AM, Margulis L, Smith DC (eds) Endocytobiology IV. Institut National de la Recherche Agivinurique, Faris, p 281-284

Fitt WK, Trench RK (1983) Endocytosis of the symbiotic dinoflagellate Symbiodinium microadriaticum Freudenthal by endodermal cell of the scyphistomae of Cassiopeia xamachana and resistance of the algae to host digestion. $\mathrm{J}$ Cell Sci 64:195-212

Freudenthal HD (1962) Symbiodinium gen. nov, and Symbiodinium microadriaticum sp. nov., a zooxanthellae: taxonomy, life cycle and morphology. J Protozool 9:45-52

Hansson LJ, Norrman B (1995) Release of dissolved organic carbon (DOC) by the scyphozoan jellyfish Aurelia aurita and its potential influence on the production of planktic bacteria. Mar Biol 121:527-532

Hoegh-Guldberg O, McCloskey LR, Muscatine L (1987) Expulsion of zooxanthellae by symbiotic cnidanans from the Red Sea. Coral Reefs 5:201-204

Hoegh-Guldberg O, Smith JS (1989) Influence of the population density of zooxanthellae and supply of ammonium on the biomass and metabolic characteristics of the reef corals Seriatopora hystrix and Stylophora pistillata. Mar Ecol Prog Ser 57:173-186

Hofmann DK, Fitt WK, Fleck J (1996) Checkpoints in the lifecycle of Cassiopea spp.: control of metagenesis and metamorphosis in a tropical jellyfish. Int J Dev Biol 40:331-338

Hofmann DK, Kremer BP (1981) Carbon metabolism and strobilation in Cassiopea andromeda (Cnidaria: Scyphozoa): significance of endosymbiotic dinoflagellates. Mar Biol. 65: $25-33$

Jassby AD, Platt T (1976) Mathematical formulation of the relationship between photosynthesis and light for phytoplankton. Limnol Oceanogr 21:540-547

Jeffrey SW, Humphrey GF (1975) New spectrophotometric equations for determining chlorophylls $a, b, c_{1}$, and $c_{2}$ in higher plants, algae, and natural phytoplankton. Biochem. Physiol Pflanz 167:191-194

Kremer P, Costello J, Kremer J, Canıno M (1990) Significance of photosynthetic endosymbionts to the carbon budget of the scyphomedusa Linuche unguiculata. Limnol Oceanogr 35(3):609-624

Lesser MP (1989) Photobiology of natural populations of zooxanthellae from the sea anemone Alptasia pallida: assess. 
ment of the host's role in protection against ultraviolet radiation. Cytometry 10:653-658

Lesser MP, Shick JM (1989a) Effects of irradiance and ultraviolet radiation on photoadaptation in the zooxanthellae of Aiptasia pallida: primary production, photoinhibition, and enzymatic defenses against oxygen toxicity, Mar Biol 102: $243-255$

Lessur MP, Shick JM (1989b) Photoadaptation and defenses against oxygen toxicity in zooxanthellae from natural populations of symbiotic cnudarians. J Exp Mar Biol Ecol 134: $129-141$

Lugo AE, Snedaker SC (1974) The ecology of mangroves. Annu Rev Ecol Syst 5:39-64

Mackey A.P, Smail G (1996) The decomposition of mangrove litter in a subtropical mangrove forest. Hydrobiologia 332: 93-98

McAuley PJ, Cook CB (1994) Effects of host feeding and dissolved ammonium on cell division and nitrogen status of zooxanthellae in the hydroid Myrionema amboinense. Mar Biol 121:343-348

McCloskey LR, Aamodt LD, Hazelton WD (1985) A computercontrolled respirometer for monitoring production and respiration of symbiotic organisms in situ. Proc 5th Int Coral Reef Congr 6:137-142

McCloskey LR, Cove TG, Verde EA (1996) Symbiont expulsion from the anemone Anthopleura elegantissima (Brandt) (Cnidaria; Anthozoa). J Exp Mar Biol Ecol 195: $173-176$

McCloskey LR, Muscatine L, Wilkerson FP (1994) Daily photosynthesis, respiration, and carbon budgets in a tropical marine jellyfish (Mastigias sp.). Mar Biol 119:13-22

McDermott AM, Blanquet RS (1991) Glucose and glycerol uptake by isolated zooxanthellae from Cassiopea xamachana: transport mechanisms and regulation by host homogenate fractions. Mar Biol 108:129-136

MCDuff RE, Chisholm SW (1982) The calculation of in situ growth rates of phytoplankton populations from fractions of cells undergoing mitosis: a clarification. Limnol Oceanogr 27:783-788

Muller-Parker G (1987) Seasonal variation in light-shade adaptation of natural populations of the symbiotic sea anemone Aiptasia pulchella (Carlgren, 1943) in Hawaii. J Exp Mar Biol Ecol 112:165-183

Muscatine L (1990) The role of symbiotic algae in carbon and energy flux in reef corals. In: Dubinsky $Z$ (ed) Coral reefs. Elsevier Science Publishers BV, Amsterdam, p 75-87

Muscatine L, Marian RE (1982) Dissolved inorganic nitrogen flux in symbiotic and nonsymbiotic medusae. Limnol Oceanogr 27:910-917

Muscatine L, McCloskey LR, Marian RE (1981) Estmating the daily contribution of carbon from zooxanthellae to coral animal respiration. Limnol Oceanogr 26:601-611

Muscatine L, Wilkerson FP, McCloskey LR (1986) Regulation of population density of symbiotic algae in a tropical marine jellyfish (Mastigias sp.). Mar Ecol Prog Ser 32 $279-290$

Newell SY, Fell JW, Statzell-Tallman A, Miller C, Cefalu RC (1984) Carbon and nitrogen dynamics in decomposing leaves of three coastal marine vascular plants of the subtropics. Aquat Bot 19:183-192

Olesen NJ, Frandsen K, Riisgard HU (1994) Population dynamics, growth and energetics of jellyfish Aurelia aurita in a shallow fjord. Mar Ecol Prog Ser 105:9-18

Parsons TR, Maita Y, Lalli CM (1984) A manual of chemical and biological methods for seawater analysis. Pergamon Press Ltd, Oxford, p 101-104

Preston RL (1993) Transport of amino acids by marne inver- tebrates. J Exp Zool 265:410-421

Prezelin BB (1987) Photosynthetic physiology of dinoflagellates. In: Taylor FJR (ed) The biology of dinoflagellates. Blackwell, Oxford, p 174-223

Rahat M, Hofmann DK (1987) Bacterial and algal effects on metamorphosis in the life cycle of Cassiopea andromeda. In: Lee JJ, Fredrick JF (eds) Endocytobiology III. New York Academy of Sciences, New York, 503:449-458

Richardson K, Beardall J, Raven JA (1983) Adaptation of unicellular algae to irradiance: an analysis of strategies. New Phytol 93:157-191

Robertson Ai (1988) Decomposition of mangrove leaf litter in tropical Australia. J Exp Mar Biol Ecol 116:235-247

Schiller C, Herndl GJ (1989) Evidence of enhanced microbial activity in the interstitial space of branched corals: possible implications for coral metabolism. Coral Reefs 7 : $179-184$

Schlichter D (1982a) Nutritional strategies of cnidarians: the absorption, translocation and utilization of dissolved nutrients by Heteroxenia fuscescens. Am Zool 22:659-669

Schlichter D (1982b) Epidermal nutrition of the alcyonarian Heteroxenia fuscescens (Ehrb.): absorption of dissolved organic material and lost endogenous photosynthates. Oecologia 53:40-49

Schlichter D (1984) Cnidaria: permeability, epidermal transport and related phenomena. In: Bereiter-Hahn J, Maltotsy AG, Richards KS (eds) Biology of the integument. 1. Invertebrates. Springer-Verlag, Berlin, p 79-95

Schlichter D, Kremer BP, Svoboda A (1984) Zooxanthellae providing assimilatory power for the incorporation of exogenous acetate in Heteroxenia fuscescens (Cnidaria: Alcyonaria) Mar Biol 83:277-286

Schlichter D, Svoboda A, Kremer BP (1983) Functional autotrophy of Heteroxenia fuscescens (Anthozoa: Alcyonaria): carbon assimilation and translocation of photosynthates from symbionts to host. Mar Biol 78:29-38

Shick JM, Dunlap WC, Chalker BE, Banaszak AT, Rosenzweig TK (1992) Survey of ultraviolet radiation-absorbing mycosporine-like amino acids in organs of coral reef holothuroids. Mar Ecol Prog Ser 90:139-148

Shick JM, Lesser MP, Dunlap WC, Stochaj WR, Chalker BE, Wu Won J (1995) Depth-dependent responses to solar ultraviolet radiation and oxidative stress in the zooxanthellate coral Acropora microphthalma. Mar Biol 122: $41-51$

Smith GJ, Hoegh-Guldberg $O$ (1987) Variation in the growth rate of zooxanthellae with coral host colony size is not controlled by changes in the duration of cytokinesis. EOS (Trans Am Geophys Un) 68:1724

Sokal RR, Rohlf FJ (1995) Biometry, 3rd edn. WH Freeman and Company, New York

Stochaj WR, Dunlap WC, Shick JM (1994) Two new UVabsorbing mycosporine-like amino acids from the sea anemone Anthopleura elegantissima and the effects of zooxanthellae and spectral irradiance on chemical composition and content. Mar Biol 118:149-156

Strathmann RR (1967) Estimating the organic carbon content of phytoplankton from cell volume or plasma volume. Limnol Oceanogr 12:411-418

Szmant AM, Forrester A (1996) Water column and sediment nitrogen and phosphorus distribution patterns in the Florida Keys, USA. Coral Reefs 15:21-41

Trench RK (1993) Microalgal-invertebrate symbioses: a review. Endocytobiosis Cell Res 9:135-175

Trench RK, Blank RJ (1987) Symbiodinium microadriaticum Freudenthal, S. goreauii, sp. nov., S. kawagutii, sp. nov., and $S$. pilosum, sp. nov: gymnodinioid dinoflagellate sym- 
bionts of marine invertebrates. J Phycol 23:469-481

Vaulot D (1992) Estimate of phytoplankton division rates by the mitotic index method: the $f_{\max }$ approach revisited. Limnol Oceanogr 37(3):644-649

Verde EA, McCloskey LR (1996) Photosynthesis and respiration of two species of algal symbionts in the anemone Anthopleura elegantissima (Brandt) (Cnidaria; Anthozoa). J Exp Mar Biol Ecol 195:187-202

Vodenichar JS (1995) Ecological physiology of the scypho-

Editorial responsibility: Otto Kinne (Editor),

Oldendorf/Luhe, Germany zoan Cassiopea xamachana. MSc thesis, University of Georgia, Athens

Wilkerson FP, Kremer P (1992) DIN, DON, AND PO flux by a medusa with algal symbionts. Mar Ecol Prog Ser 90:237-250

Wilkerson FP, Muller-Parker G, Muscatine L (1983) Temporal patterns of cell division in natural populations of endosymbiotic algae. Limnol Oceanogr 28:1009-1014

Zar JH (1996) Biostatistical analysis, 3rd edn. Prentice Hall, Englewood Cliffs

Submitted. July 8, 1997; Accepted: March 3, 1998

Proofs received from author(s): June 12, 1998 